\title{
The role of horizontal and vertical new product alliances in responsive and proactive market orientations and performance of industrial manufacturing firms
}

\author{
Sena Ozdemir ${ }^{\mathrm{a}, *}$, Destan Kandemir ${ }^{\mathrm{b}}$, Teck-Yong Eng ${ }^{\mathrm{c}}$ \\ a Essex Business School, University of Essex, Elmer Approach, Southend-on-Sea SS1 1LW, United Kingdom \\ ${ }^{\mathrm{b}}$ Department of Management, Bilkent University, Bilkent, Ankara 06800, Turkey \\ c Southampton Business School, University of Southampton, Building 2, Highfield Campus, Southampton S017 1BJ, United Kingdom
}

\section{A R T I C L E I N F O}

\section{Article history:}

Received 21 July 2015

Received in revised form 3 March 2017

Accepted 24 March 2017

Available online 29 March 2017

\section{Keywords:}

Business-to-business new product alliances

Proactive market orientation

Responsive market orientation

New product performance

Organizational learning

\begin{abstract}
A B S T R A C T
This study examines different roles of new product alliance partners in enhancing responsive market orientation (RMO) and proactive market orientation (PMO) of industrial manufacturing firms in the context of learning in business-to-business (B2B) relationships. A survey of 146 firms shows that horizontal new product alliances with competitors provide access to similar industrial knowledge and know-how and thus help improve a manufacturing firm's RMO through exploitative learning. Although vertical new product alliances with suppliers may grant access to similar domains of knowledge, the findings of this study do not provide any support for their effect on a manufacturing firm's RMO. In contrast, the study shows that vertical new product alliances with research institutions provide access to a broader knowledge base and greater know-how with higher levels of non-redundancy and thus help improve a PMO through explorative learning. In addition, the results suggest that both RMO and PMO developed in different types of new product alliances enable a manufacturing firm to improve its new product performance and eventually its overall performance.
\end{abstract}

(c) 2017 Elsevier Inc. All rights reserved.

\section{Introduction}

Business-to-business (B2B) new product relationships (hereinafter, new product alliances) with different types of alliance partners, including horizontally and vertically connected partners, can provide several benefits to participating firms, such as easier access to new knowledge, reduced costs and risks associated with developing new products, and enhanced opportunities for gaining new competencies (Rindfleisch \& Moorman, 2003; Thomas, 2013; Xu, Wu, \& Cavusgil, 2013). However, although new product alliances can be beneficial for participating firms, they may not produce value for or meet the diverse needs of their customers (Garud, 1994; Rindfleisch \& Moorman, 2003). From a market orientation (MO) perspective, firms may adopt a responsive and/or proactive MO approach to satisfy customer needs. Learning from diverse types of alliance partners (i.e., competitors, suppliers, and research institutions) may help support either responsive or proactive MO (Koza \& Lewin, 1998). This study examines the potential for partnering firms to develop a responsive market orientation (RMO) and/or proactive market orientation (PMO) through their involvement in new product alliances and, thus, to enhance their new product and firm performance.

\footnotetext{
* Corresponding author.

E-mail addresses: sozdemir@essex.ac.uk (S. Ozdemir), destan@bilkent.edu.tr (D. Kandemir), T.Y.Eng@soton.ac.uk (T.-Y. Eng).
}

RMO pertains to a firm's set of behaviors prioritized on the creation of superior value for expressed or current customer needs (Narver, Slater, \& MacLachlan, 2004; Rindfleisch \& Moorman, 2003; Slater \& Narver, 1995; Yannopoulos, Auh, \& Menguc, 2012). Conversely, PMO focuses on understanding and creating distinctive value for customers' latent or future needs (Narver et al., 2004; Slater \& Narver, 1995; Yannopoulos et al., 2012). Although responding to expressed customer needs through RMO plays a critical role in achieving short-term value creation, proactively addressing latent customer needs through PMO helps ensure an ongoing value-creation process (Blocker, Flint, Myers, \& Slater, 2011). In B2B marketing, new product alliances provide the potential for partners to develop successful performance outcomes through both RMO and PMO.

Extant B2B marketing studies have mainly focused on the role of B2B dyadic relationships in a firm's RMO toward expressed customer needs within a vertical channel system (Hernandez-Espallardo \& Arcas-Lario, 2003; Rindfleisch \& Moorman, 2003) and in horizontal alliances with competitors (Rindfleisch \& Moorman, 2003). However, evidence on how new product alliances affect the development of PMO is lacking. Some empirical studies have examined how new product alliances affect firm behaviors by using insights from entrepreneurial orientation and innovativeness (Antoncic \& Prodan, 2008; Duysters \& Lokshin, 2011; George, Zahra, \& Wood, 2002; Inemek \& Matthyssens, 2013), but to date, no studies have examined the relationship between new product alliances and PMO. Moreover, they do not make any direct 
inferences on how the roles of horizontal and vertical new product alliances may differ in creating RMO and/or PMO.

Furthermore, how vertical new product alliances with suppliers or research institutions may affect a firm's MO remains unclear. From an organizational learning perspective, research institutions, which possess a broader knowledge base than other vertical alliance partners (e.g., suppliers), may not necessarily have the same effect on their partner firms' MO (Un, Cuervo-Cazurra, \& Asakawa, 2010). In addition, there is limited research on the performance implications of MO in a B2B alliance context (Siguaw, Simpson, \& Baker, 1998). In the context of B2B marketing, business relationships can maximize the effect of a firm's level of orientation toward expressed and latent market needs on its performance (Boso, Story, \& Cadogan, 2013).

This study addresses these voids by examining the effects of diverse types of new product alliances, including horizontal alliances with competitors and vertical alliances with suppliers and research institutions, on an industrial manufacturing firm's level of RMO and PMO and, in turn, its new product and firm performance. Drawing from organizational learning theory and research on MO, we assume that horizontal new product alliances with competitors and vertical new product alliances with suppliers help develop a firm's RMO through exploitative learning in the creation of value for expressed customer needs. We also assume that vertical new product alliances with research institutions help develop a firm's PMO through exploratory learning in the creation of value for latent customer needs. Finally, we propose that RMO and PMO developed in different types of new product alliances subsequently help enhance a firm's new product performance and overall performance.

\section{Theoretical background}

MO involves generating intelligence about the market and, in particular, customer needs and preferences, disseminating that intelligence across a firm's diverse functional units, and responding to such intelligence in the form of organizational operations (Kohli \& Jaworski, 1990; Slater \& Narver, 1995). In B2B marketing, MO has been examined in the context of dyadic business relationships (e.g., Elg, 2002, 2007). In today's product-market competition, allying with a network of partners in new product development (NPD) ensures economies of scale in processing market information and helps firms keep pace with changing customer needs and market velocity to achieve new ways of delivering superior customer value (Day, 2011; Elg, 2007). Thus, it is important to understand how a firm's MO emerges as a result of different learning practices occurring in the firm's alliances.

However, research has criticized the MO concept for its exclusive focus on expressed customer needs (Narver et al., 2004; Yannopoulos et al., 2012). Several marketing scholars assert that focusing too closely on current customers makes firms become insensitive to emerging market needs and often leads them to lose their positions of industry leadership (Christensen \& Bower, 1996; Narver et al., 2004; Yannopoulos et al., 2012). Thus, it is necessary to address latent customer needs for achieving a sustainable competitive advantage (Narver et al., 2004; Yannopoulos et al., 2012). These criticisms have led to the identification of two facets of MO: responsive and proactive (Atuahene-Gima, Slater, \& Olson, 2005; Narver et al., 2004; Saini \& Johnson, 2005; Slater \& Mohr, 2006). RMO and PMO comprise the sets of behaviors that are based on a firm's attempts to address the two forms of customer needs: expressed and latent.

Responsive market-oriented firms generate deep insights into customers' wants and needs of current solutions through techniques such as customer surveys and conjoint analysis (Atuahene-Gima et al., 2005; Jaeger, Zacharias, \& Brettel, 2016; March, 1991; Slater \& Narver, 1998). However, RMO reduces the likelihood of generating competitive new solutions with superior customer value (Berghman, Matthyssens, \& Vandenbempt, 2006) and a high degree of novelty (Narver et al., 2004); such a focus results in learning myopia, which impedes the generation of creative responses to emerging technologies and customer needs (Atuahene-Gima \& Ko, 2001). In this sense, RMO is generated through and thus reflects exploitative learning behavior (Atuahene-Gima et al., 2005; Baker \& Sinkula, 2005; Jaworski, Kohli, \& Sahay, 2000; Jiménez-Jiménez \& Cegarra-Navarro, 2007; Morgan \& Berthon, 2008; Narver et al., 2004; Tsai, Chou, \& Kuo, 2008; Yannopoulos et al., 2012; Zhang, Wu, \& Cui, 2015). According to Koza and Lewin (1998, p. 256), exploitation involves "refining and improving existing capabilities and technologies, standardization, routinization, and systematic cost reduction." The key objectives of firms engaging in knowledge exploitation are to maintain the status quo and deepen existing knowledge and know-how to optimize and exploit them in current product markets (March, 1991; Yannopoulos et al., 2012).

In contrast, PMO is the attempt to discover new market opportunities by uncovering and satisfying customers' latent and future needs, which are not in their consciousness (Morgan \& Berthon, 2008; Narver et al., 2004). This type of approach requires an outside-in process that puts greater emphasis on exploration of changing customer needs and market trends. Proactive market-oriented firms actually lead customers (Narver et al., 2004); they also often work closely with lead users who have needs that are well ahead of mainstream customers (Jaeger et al., 2016; Slater \& Narver, 1998; Von Hippel, 1986). Proactive market-oriented firms are sufficiently flexible to develop a diverse range of promising ideas to create novel customer solutions without being constrained by their existing knowledge, mental models, practices, and know-how (Jiménez-Jiménez \& Cegarra-Navarro, 2007; Narver et al., 2004; Saini \& Johnson, 2005). They nurture an experimental mindset by challenging existing beliefs and encouraging an open learning climate in which learning from market failure is acceptable and experimentation is the norm (Day, 2011). In this regard, PMO is generated through and thus reflects explorative learning behavior (Baker \& Sinkula, 2007; Jiménez-Jiménez \& Cegarra-Navarro, 2007; Morgan \& Berthon, 2008). It is also parallel to the concept of vigilant market learning, which requires an open-minded and exploratory approach to be able to sense and act on weak signals about latent customer needs (Day, 2011). According to March (1991, p. 71), "exploration includes things captured by terms such as search, variation, risk taking, experimentation, play, flexibility, discovery, innovation." PMO may, at least, change entrenched customer practices and behavior and, at best, transform the whole market or industry structure and conduct (Berghman et al., 2006; Jaworski et al., 2000; Kumar, Scheer, \& Kotler, 2000; Narver et al., 2004).

\section{Hypotheses}

NPD is a strategic activity in which firms may use new product alliances to create superior customer value and improve business performance (Lambe, Morgan, Sheng, \& Kutwaroo, 2009; Lin, Wu, Chang, Wang, \& Lee, 2012; Rindfleisch \& Moorman, 2001, 2003). New product alliances refer to formalized collaborative arrangements among two or more organizations to jointly acquire and use knowledge related to the research and development (R\&D) and/or the commercialization of new products/processes (Rindfleisch \& Moorman, 2001). Firms can achieve a sustainable competitive advantage by accessing this knowledge, particularly tacit knowledge, which is valuable, rare, and difficult to imitate and substitute (Barney, 1991). In a B2B alliance context, firms have the potential to exhibit market-oriented behaviors as a result of learning through their dyadic interactions with other organizations.

Drawing from March's (1991) exploration-exploitation framework of organizational learning, we suggest that firms forming alliances with different organizations show differences in their learning motivations and practices (Koza \& Lewin, 1998). Some firms may jointly exploit their existing knowledge and know-how, while others may explore new opportunities. New product alliances emphasizing exploration are more likely to develop new knowledge and discover more innovative solutions for customers (Hoang \& Rothaermel, 2010). In contrast, new product alliances focusing on exploitation expend efforts to deepen existing knowledge by making incremental changes and 
improvements to current customer solutions (Hoang \& Rothaermel, 2010; Levitas \& McFadyen, 2009).

Although previous research has rarely differentiated new product alliances according to the type of organization (i.e., competitor, supplier, and research institution) that a firm allies with (Rindfleisch \& Moorman, 2001, 2003; Xu et al., 2013), our study differentiates between horizontal and vertical new product alliances to provide a better understanding of the effect of different types of new product alliances on MO. While horizontal alliances include B2B cooperative relationships between competitors (Galaskiewicz, 1985; Pfeffer \& Nowak, 1976), vertical alliances involve cooperative relationships between a firm and its value-chain members (e.g., suppliers, research institutions) (Rindfleisch \& Moorman, 2001).

\subsection{Horizontal alliances and $M O$}

Organizational learning scholars argue that inputs required for knowledge exploitation (i.e., similar and redundant knowledge) often lie within a firm's own industry (Rindfleisch \& Moorman, 2003). As horizontal alliance partners hold a common position on the value chain and operate in same-product markets and industries, their knowledge bases and know-how overlap to a great extent (Rindfleisch \& Moorman, 2001; $\mathrm{Xu}$ et al., 2013). Therefore, allying with competitors only improves a firm's depth of knowledge in a narrow range of closely related knowledge domains (Cohen \& Levinthal, 1990; Lane, Koka, \& Pathak, 2006) and supports capabilities in creating new customer solutions in the realm of older, existing ones (Makri, Hitt, \& Lane, 2010; Nelson \& Winter, 1982; Rindfleisch \& Moorman, 2001, 2003). In other words, the industrial knowledge redundancy and shared knowledge structures between horizontal alliance partners reinforce path-dependent and routine-based learning and stimulate external knowledge absorption and utilization geared toward developing customer-based solutions for expressed needs (Nelson \& Winter, 1982; Rindfleisch \& Moorman, 2001). In horizontal new product alliances, exploitative learning in the creation of new product solutions is thus likely to be associated with a firm's RMO (Rindfleisch \& Moorman, 2001).

Although horizontal alliance partners may own non-redundant knowledge or intend to explore new market opportunities (Xu et al., 2013), psychological barriers still exist between partners of the same type when engaging in joint product development for knowledge exploration. To maintain their unique knowledge base, reduce competition intensity, and lower the risk of being exposed to out-learning and de-skilling by their competitors, horizontal alliance partners are often reluctant to share the bits of new knowledge that would have the potential to generate long-term competitive advantages (Baum, Calabrese, \& Silverman, 2000; Kotabe, Mol, \& Murray, 2008; Love \& Gunasekaran, 1999). Firms that engage in alliances with organizations that have similar knowledge and know-how want to protect their status quo (Garud, 1994) and thus tend to align their product development practices with the requirements of current customers and the marketplace (Rindfleisch \& Moorman, 2003). This view is corroborated in previous studies, which report that compared with different types of vertical alliance partners, horizontal alliances with competitors tend to be the least effective way of satisfying latent customer needs (to produce highly novel products) (Mention, 2011; Monjon \& Waelbroeck, 2003; Nieto \& Santamaria, 2007; Rindfleisch \& Moorman, 2003; Xu et al., 2013). Thus, increased familiarity with a given customer knowledge domain leads horizontal alliance partners to become more RMO focused. Therefore:

H1. The extent of a firm's alliances with competitors in NPD is positively associated with its RMO.

\subsection{Vertical alliances and $M O$}

Vertical alliance partners, operating at different points along the value chain, often own both complementary and dissimilar knowledge and know-how in product development (Rindfleisch \& Moorman, 2003; Vanhaverbeke, Gilsing, Beerkens, \& Duysters, 2009). Such diverse groups of firms may grant access to novel sources of knowledge and enhance a firm's breadth of knowledge in an extensive range of loosely related knowledge domains (Burt, 1992; Lane et al., 2006; Vanhaverbeke et al., 2009).

For a firm, suppliers and research institutions constitute vertical alliance partners along its vertical chain. Suppliers operate both within the same industry as manufacturers and across different industries. Thus, they add complementary knowledge to that of manufacturing firms, but they also have distinct industrial and market knowledge (Hess \& Rothaermel, 2011; Rindfleisch \& Moorman, 2003; Vanhaverbeke et al., 2009). Research institutions are types of firms operating in different industries, such as the higher education institute sector. Organizational learning theorists argue that inputs required for knowledge exploration (i.e., novel and non-redundant knowledge) often lie outside a firm's own industry (Rindfleisch \& Moorman, 2003). This logic assumes that research institutions have different learning objectives and know-how than those of commercial manufacturers.

The literature on B2B relationships suggests that suppliers often contribute to a greater extent to market intelligence-gathering activities and learning for the types of solutions targeting expressed customer needs (Menguc, Seigyoung, \& Yannopoulos, 2014; Song \& Thieme, 2009). From a supplier's perspective, an important reason for this is the alliance performance measurements used to assess suppliers. In particular, manufacturers often measure the performance of their suppliers in the context of operational improvements, quality, time, and costs (Cousins \& Lawson, 2007; De Toni \& Nassimbeni, 2001). As a result, suppliers serve as ideal sources for achieving superior operational outcomes in terms of understanding existing customers and engaging in exploitative learning to refine current solutions through quality, design, and price improvements (Belderbos, Carree, Diederen, Lokshin, \& Veugelers, 2004; Lhuillery \& Pfister, 2009; Nieto \& Santamaria, 2007; Thomas, 2013).

However, supporting manufacturers with learning to create new solutions for latent customer needs may be too costly for suppliers. Doing so may require active involvement, frequent and intensive interactions, and risk sharing of suppliers with manufacturers. In addition, suppliers often avoid giving costly, irreversible commitments to manufacturing projects that are dependent on emerging customer needs with high levels of uncertainty (Bonaccorsi \& Lipparini, 1994; Cousins \& Lawson, 2007; Dyer \& Singh, 1998). In line with this view, Koufteros, Vonderembse, and Jayaram (2005) find that the impact of new product alliances with suppliers on the development of highly innovative solutions is significant and negative. They attribute these findings to the idea that the development of such solutions requires assigning more tasks to suppliers; this, in turn, has detrimental effects on a manufacturer's learning of how to integrate market intelligence about latent customer needs into NPD.

From a manufacturer's perspective, the potential leak of commercially sensitive information to competitors through shared suppliers may discourage manufacturers from undertaking co-development activities for the creation of highly innovative products that address latent customer needs (Belderbos et al., 2004). Instead, manufacturing firms may be motivated to engage in exploitative learning practices in vertical new product alliances with suppliers to deepen their existing industrial knowledge and know-how and to create value for expressed customer needs, leading to the development of their RMO (Lane et al., 2006). Thus:

H2. The extent of a firm's alliances with suppliers in NPD is positively associated with its RMO.

Research institutions are vertical alliance partners with a broader and/or deeper knowledge base than other types of firms. Such upstream 
alliance partners become involved in discovery and breakthroughs to advance scientific research and lend support to commercializing highly innovative solutions related to latent customer needs (Bercovitz \& Feldman, 2007). They improve a manufacturer's internal R\&D activities by providing access to unique knowledge and know-how absent within the firm (Belderbos et al., 2004; Bercovitz \& Feldman, 2007; Hess \& Rothaermel, 2011; Hoang \& Rothaermel, 2010; Lane \& Lubatkin, 1998).

Vertical new product alliances with research institutions can help manufacturers learn how to create unique customer solutions for latent customer needs using new variants of knowledge emerging from longterm academic research (Mansfield, 1991). For example, Rolls-Royce has established vertical new product alliances with different research institutions through its University Technology Centres located at several universities around the world. These alliances have helped the firm recognize new market opportunities, expand its R\&D know-how in different industrial and technology domains, and introduce several breakthrough solutions addressing the future technology needs of its customers (Lambert, 2003). In addition, during new product alliances, the potential for opportunism is low for research institutions, as they are independent of competitive pressures and industrial constraints and have different objectives than the private sector (Bercovitz \& Feldman, 2007). As such, firms are motivated to engage in vertical new product alliances with research institutions to undertake exploratory learning practices for the creation of highly innovative solutions targeting latent customer needs, leading to the development of their PMO. Thus:

H3. The extent of a firm's alliances with research institutions in NPD is positively associated with its PMO.

\section{3. $R M O$ and new product performance}

Previous research provides strong empirical evidence of the positive effect of RMO on new product performance (Atuahene-Gima, 1995, 1996; Baker \& Sinkula, 2005; Gotteland \& Boule, 2006; Henard \& Szymanski, 2001; Langerak, Hultink, \& Robben, 2004; Lukas \& Ferrell, 2000; Narver et al., 2004; Paladino, 2007; Pelham \& Wilson, 1996; Slater \& Narver, 1994; Wei \& Morgan, 2004). Firms emphasizing RMO learn about the marketplace, identify current customer needs, and understand their competitors' positions (Kohli \& Jaworski, 1990; Narver \& Slater, 1990). In turn, they can integrate this accumulated market knowledge into their NPD activities, and develop quality products that meet or exceed customer expectations (Day \& Nedungadi, 1994; Kohli \& Jaworski, 1990; Narver \& Slater, 1990). A greater familiarity with a given market knowledge domain often results in incrementally new products that satisfy current customers' needs through refinements and/or improvements to existing products and technologies (Yannopoulos et al., 2012). Thus, firms with higher levels of RMO are likely to exhibit greater new product performance and achieve their market share and sales objectives through experience and by adopting more cost-efficient ways of creating product solutions.

Despite these advantages, RMO can become detrimental to new product performance. Both Atuahene-Gima et al. (2005) and Tsai et al. (2008) suggest an inverted U-shaped relationship between RMO and new product performance. RMO emphasizes exploitation and involves a thorough and detailed processing of the firm's pre-existing knowledge about current customers and their expressed needs (Atuahene-Gima et al., 2005; March, 1991; Yannopoulos et al., 2012). As a result, RMO-focused firms are characterized by a product innovation culture that promotes efficiencies, refinement, and routinization and offers products with only incremental differences from the previous ones (Atuahene-Gima et al., 2005; March, 1991; Yannopoulos et al., 2012). While firms exhibit increasing returns as they become competent in an existing operational domain, the positive mutual feedback between experience and competence may lead them into a familiarity trap, which makes the search for new knowledge less attractive (Cohen \& Levinthal, 1990; Tsai et al., 2008). When RMO exceeds a certain level, firms may pay little attention to developing new insights into valueadding opportunities, discovering alternative ways of innovating products, and offering new and differentiated product benefits. Therefore, firms with an excessive RMO cannot innovate products/technologies outside their range and scope of products or markets, and they carry the risk of failing to adapt quickly to changes in market conditions and technologies. Thus:

H4. The relationship between RMO and new product performance has an inverted $U$ shape.

\subsection{PMO and new product performance}

The link between PMO and new product performance has recently attracted some attention from MO and NPD researchers. Some studies suggest that PMO directly and positively influences new product performance (Narver et al., 2004; Zhang \& Duan, 2010), while others suggest that there is an inverted U-shaped relationship between PMO and new product performance (Atuahene-Gima et al., 2005; Tsai et al., 2008). The current study further investigates this relationship in a market context which is characterized by a strong high uncertainty avoidance (Hofstede, 2001). Since in higher uncertainty avoidance environments, there will also be high resistance to changes in existing consumption practices for innovative offerings (Waarts \& Van Everdingen, 2005), this study proposes a strong inverted U-shaped effect of PMO on new product performance.

PMO involves organizational learning processes for exploring the latent needs of current and potential customers. Specifically, it stimulates the discovery and implementation of solutions to address the identified customer needs. Thus, PMO allows firms to achieve greater new product performance by alerting them to technological developments and new product-market opportunities for developing radical products with unique benefits. As such, PMO-focused firms provide greater product differentiation (Kim \& Atuahene-Gima, 2010; Voola \& O'Cass, 2010), introduce more innovative products (Katila, 2000; Li, Lin, \& Chu, 2008), and generate greater customer value (Blocker et al., 2011) than their RMO-focused counterparts.

However, excessive PMO may hinder the success of new products. By its very nature, a PMO approach emphasizes exploration. Proactive market-oriented firms are likely to search for, integrate, and use new information to address the latent needs of customers and future customers (Atuahene-Gima et al., 2005; Yannopoulos et al., 2012). With such a focus, firms with a PMO are able to integrate new variants of market information in product development. As PMO emphasizes un-learning core organizational competencies (which can become core rigidities over time) and broadening the scope of product innovation knowledge and competencies by learning from a diverse range of sources (Katila, 2000; Morgan \& Berthon, 2008), too much knowledge exploration may lead to inefficiencies due to a focus on unfamiliar information and knowledge (Atuahene-Gima et al., 2005; Tsai et al., 2008). As such, PMO-focused firms may become involved in too many exploratory NPD projects that shift their focus away from current markets. Moreover, NPD teams may collect information that is too distant from current markets, which may result in the creation of ineffective product solutions. Thus, excessive PMO may diminish the firm's focus on developing new products that meet the needs of current markets and thus create customer resistance to adopting the products launched, thereby limiting product success. This leads to the following:

H5. The relationship between PMO and new product performance has an inverted $U$ shape. 
3.5. The mediating effect of new product performance on the relationship between RMO and PMO and firm performance

Research in marketing strategy has established a positive link between MO and firm performance (e.g., Grewal \& Tansuhaj, 2001; Hult \& Kethchen, 2001; Jaworski \& Kohli, 1993; Matsuno \& Mentzer, 2000; Slater \& Narver, 1994). However, few studies have focused on the paths through which MO affects a firm's performance (for a review, see Kirca, Jayachandran, \& Bearden, 2005). This is mainly because marketing scholars often reason that the MO-firm performance relationship derives from promotion, pricing, and distribution strategies (Baker \& Sinkula, 1999). However, while promotion and distribution functions can be easily outsourced, manufacturing firms often need to have greater involvement in their product development practices with other firms (Baker \& Sinkula, 1999). Thus, the relationship between MO and firm performance, at least in part, depends on the extent to which new products are successfully developed and brought to the market (Kirca et al., 2005; Langerak et al., 2004; Narver et al., 2004).

We examine MO as a two-dimensional concept and investigate whether new product performance mediates the effects of RMO and PMO on firm performance. Although some research has empirically observed the mediating effects of innovation and new product performance on the relationship between RMO and firm performance (Han, Kim, \& Srivastava, 1998; Zhou, Yim, \& Tse, 2005), such effects on the PMO-firm performance relationship have not been investigated. The effects of RMO and PMO on firm performance may greatly depend on how firms use these orientations to respond to customer needs in the form of new products. Considering the importance of NPD on a firm's overall success in the market, we propose that the benefits of RMO and PMO for firm performance depend on its new product performance. Thus:

H6. New product performance has a mediating effect on the relationship between (a) RMO and (b) PMO and firm performance.

\section{Research method}

\subsection{Sample and data collection}

The sampling frame of this research came from the Turkish Statistical Institute, which provided access to a list of 800 industrial manufacturing firms operating in high- and medium-high-technology industries in Turkey. Examples to medium-high technology industries include sectors such as chemicals, motor vehicles and transport equipment etc. (OECD, 2013). A structured Internet-based questionnaire served to collect data on the types of MO and new product alliances adopted by the respondent firms, as well as their new product and firm performance. The questionnaire was originally designed in English and then parallel-translated into Turkish by two independent translators. We then merged the parallel translations into a final draft, which was then back-translated into English by an independent translator to check the nuances of translations in the source and target languages. We also pilot-tested the questionnaire with several academics and professionals to eliminate potential ambiguities and improve the clarity of the questions and the face validity of the items.

In the first stage of data collection, we called all the firms in the sampling frame to determine whether they had engaged in any type of alliance with other firms in the last five years. If so, we asked about their willingness to take part in our research and noted the contact details of the senior manager or any other executive responsible for NPD projects and the related alliance relationships. The screening procedure identified 548 firms that were eligible for participation. Next, we emailed a personalized message requesting consent for participation in the research and a web link to the questionnaire to each respondent. We assured respondents' confidentiality by making no mention of their identities in any published material. Two months after the initial emails, we sent a reminder to non-respondents. In total, 176 responses were collected, for a response rate of $32 \%$. After elimination of responses with too much missing data, 146 effective responses remained. We assessed non-response bias by comparing early and late respondents on each variable (Armstrong \& Overton, 1977). The $t$-test results revealed no statistically significant differences between the two groups; thus, non-response bias is not an issue in the data.

The respondents consisted of senior managers, including CEOs (12\%), sales and marketing managers (44\%), R\&D/product/project development managers (35\%), production and planning managers (5\%), and accounts and finance managers (4\%) operating in the industries of electrical and electronic machinery (70\%), chemicals (18\%), and automotive (i.e., auto manufacturers) (12\%). The sample firms employed 625 full-time employees on average: $22 \%$ employed fewer than 50 employees, 63\% employed between 40 and 499 employees, 13\% employed between 500 and 4999 employees, and 2\% employed 5000 or more employees. The average firm age was 34 years, and firms were located in different regions of Turkey.

\subsection{Measurement}

Table 1 details the constructs and their operationalization. All the measures used in this study were at the firm level, with the exception of competitive intensity, which is an industry-level measure. We measured RMO and PMO using multi-item scales developed by Narver et al. (2004). RMO refers to the extent to which firms exert efforts to understand existing customer needs, assess customer satisfaction, and satisfy the current needs of customers; PMO refers to the extent to which they search for new and diverse knowledge to satisfy latent customer needs. We used a seven-point Likert-type scale $(1=$ not at all, $7=$ to an extreme extent) to measure RMO and PMO.

We measured new product performance, which represents the commercial performance of new products, using four items adopted from Atuahene-Gima and Ko (2001) and Moorman (1995). The four-item scale evaluated the extent to which the firm's new products/services achieve market share, sales and profit. We used a seven-point Likerttype scale ( $1=$ very strongly disagree, $7=$ very strongly agree) to measure new product performance. Finally, again using a seven-point Likert-type scale ( 1 = very dissatisfied, 7 = very satisfied), we measured firm performance with four items adopted from Kirca et al. (2005); we also assessed the extent to which the firm is satisfied with its financial performance.

We focus on two types of new product alliances: horizontal and vertical. Horizontal alliances involve a firm's partnership with competitors, while vertical alliances may include partnership with suppliers or research institutions (Lhuillery \& Pfister, 2009; Rindfleisch \& Moorman, 2001, 2003). In particular, the new product alliance measures asked the extent to which the sample firms engaged in formalized and dyadic arrangements that involved the co-development of new products with other alliance partners during NPD. Using a seven-point Likert-type scale ( $1=$ not at all, $7=$ to a great extent), we measured competitor, supplier, and research institution alliances with a single item that tapped the extent to which the firm had developed partnerships in its NPD activities with competitors, suppliers, and universities/higher education institutes, respectively (Faems, de Visser, Andries, \& Van Looy, 2010; Lhuillery \& Pfister, 2009; Zeng, Xie, \& Tam, 2010).

Firm age and competition intensity served as control variables. In the analysis, we used the logarithm of age to represent this variable. Using a seven-point Likert-type scale ( 1 = very strongly disagree, 7 = very strongly agree), we measured competition intensity with five items adopted from Jaworski and Kohli (1993). Table 2 presents the means, standard deviations, and correlation matrices of study constructs. 
Table 1

Results of the CFA.

\begin{tabular}{|c|c|c|}
\hline Scale items & $\begin{array}{l}\text { Standardized } \\
\text { loading }\end{array}$ & t-Value ${ }^{a}$ \\
\hline \multicolumn{3}{|c|}{ Responsive market orientation $(A V E=59.64 \% ; H S V=36.72 \% ; C R=0.81)$} \\
\hline $\begin{array}{l}\text { Our business objectives are driven primarily by } \\
\text { customer satisfaction. }\end{array}$ & 0.80 & 10.82 \\
\hline $\begin{array}{l}\text { We constantly monitor our level of commitment and } \\
\text { orientation to serving customer needs. }\end{array}$ & 0.86 & 12.17 \\
\hline $\begin{array}{l}\text { We freely communicate information about our } \\
\text { successful and unsuccessful customer experiences } \\
\text { across all business functions. }\end{array}$ & 0.64 & 8.01 \\
\hline \multicolumn{3}{|l|}{$\begin{array}{l}\text { Our strategy for competitive advantage is based on our } \\
\text { understanding of customers' needs. }\end{array}$} \\
\hline $\begin{array}{l}\text { We measure customer satisfaction systematically and } \\
\text { frequently. }\end{array}$ & 0.70 & 9.00 \\
\hline \multicolumn{3}{|l|}{ We are more customer focused than our competitors. ${ }^{\mathrm{b}}$} \\
\hline $\begin{array}{l}\text { I believe this business exists primarily to serve } \\
\text { customers. }\end{array}$ & 0.73 & 9.56 \\
\hline \multicolumn{3}{|l|}{$\begin{array}{l}\text { Data on customer satisfaction are disseminated at all } \\
\text { levels in this business unit on a regular basis. }{ }^{\text {b }}\end{array}$} \\
\hline \multicolumn{3}{|c|}{ Proactive market orientation $(A V E=58.92 \% ; H S V=36.72 \% ; C R=0.88)$} \\
\hline $\begin{array}{l}\text { We help our customers anticipate developments in their } \\
\text { markets. }\end{array}$ & 0.66 & 8.45 \\
\hline $\begin{array}{l}\text { We continuously try to discover additional needs of our } \\
\text { customers of which they are unaware. }\end{array}$ & 0.82 & 11.29 \\
\hline \multicolumn{3}{|l|}{$\begin{array}{l}\text { We incorporate solutions to unarticulated customer } \\
\text { needs in our new products and services. }\end{array}$} \\
\hline \multicolumn{3}{|l|}{$\begin{array}{l}\text { We brainstorm on how customers use our products and } \\
\text { services. }^{\text {b }}\end{array}$} \\
\hline $\begin{array}{l}\text { We innovate even at the risk of making our own } \\
\text { products obsolete. }\end{array}$ & 0.69 & 8.85 \\
\hline \multicolumn{3}{|l|}{$\begin{array}{l}\text { We search for opportunities in areas where customers } \\
\text { have a difficult time expressing their needs. }{ }^{\text {b }}\end{array}$} \\
\hline $\begin{array}{l}\text { We work closely with lead users who try to recognize } \\
\text { customer needs months or even years before the } \\
\text { majority of the market may recognize them. }\end{array}$ & 0.81 & 11.07 \\
\hline $\begin{array}{l}\text { We extrapolate key trends to gain insight into what } \\
\text { users in a current market will need in the future. }\end{array}$ & 0.84 & 11.71 \\
\hline \multicolumn{3}{|c|}{ New product performance $(A V E=88.37 \% ; H S V=27.35 \% ; C R=0.96)$} \\
\hline $\begin{array}{l}\text { New products/services at my firm generally achieved } \\
\text { their market share objectives in the last } 3 \text { years. }\end{array}$ & 0.95 & 15.16 \\
\hline $\begin{array}{l}\text { New products/services at my firm generally achieved } \\
\text { their sales and customer use objectives in the last } \\
3 \text { years. }\end{array}$ & 0.94 & 14.71 \\
\hline $\begin{array}{l}\text { New products/services at my firm generally achieved } \\
\text { their sales growth objectives in the last } 3 \text { years. }\end{array}$ & 0.93 & 14.40 \\
\hline $\begin{array}{l}\text { New products/services at my firm generally achieved } \\
\text { their profit objectives in the last } 3 \text { years. }\end{array}$ & 0.80 & 11.25 \\
\hline \multicolumn{3}{|l|}{ Firm performance $(A V E=73.33 \% ; H S V=27.35 \% ; C R=0.92)$} \\
\hline Firm's sales growth in the past 3 years. & 0.75 & 10.29 \\
\hline Firm's profitability in the past 3 years. & 0.80 & 11.28 \\
\hline ROI or IRR in the past 3 years. & 0.95 & 14.87 \\
\hline Growth in ROI in the past 3 years. & 0.90 & 13.56 \\
\hline \multicolumn{3}{|l|}{ Competition intensity $(A V E=39.90 \% ; H S V=0.48 \% ; C R=0.66)$} \\
\hline Competition in our industry is cutthroat. & 0.64 & 7.60 \\
\hline There are many 'promotion wars' in our industry. & 0.57 & 6.58 \\
\hline $\begin{array}{l}\text { Anything that one competitor can offer, others can } \\
\text { match readily. }\end{array}$ & 0.68 & 8.14 \\
\hline Price competition is a hallmark of our industry. & 0.60 & 7.00 \\
\hline One hears of a new competitive move almost every day. & 0.76 & 9.25 \\
\hline
\end{tabular}

Model fit statistics: $\chi^{2}=302.81(\mathrm{df}=220, p<0.05)$; NNFI $=0.95 ; \mathrm{CFI}=0.96$; $\mathrm{IFI}=0.96$ RMSEA $=0.05 ; 90 \%$ confidence interval of RMSEA $=(0.04,0.07)$.

Notes: AVE = average variance extracted; HSV = highest shared variance with other constructs; $\mathrm{CR}=$ composite reliability.

a The t-values from the unstandardized solution.

b Items deleted from scale.

\section{Analysis and results}

\subsection{The measurement model}

We evaluated the measures' psychometric properties using a confirmatory factor analysis (CFA) (Anderson \& Gerbing, 1988; Bagozzi, Yi, \&
Phillips, 1991). This approach resulted in a CFA that included five factors: RMO, PMO, new product performance, firm performance, and competition intensity. The CFA was fitted using the maximum likelihood estimation procedure, with the raw data input as in EQS 6.1 (Bentler, 1995). After we dropped items with low factor loadings or high cross-loadings, the confirmatory model fit the data satisfactorily. Table 1 details the constructs and retained items.

We assessed the convergent and discriminant validity of the focal constructs. Each measurement item loaded only on its latent construct. The chi-square test for our theoretical variables was statistically significant $\left(\chi_{(220)}^{2}=302.81, p<0.05\right)$. The Bentler-Bonett non-normed fit index (NNFI), the comparative fit index (CFI), Bollen's incremental fit index (IFI), and the root mean square error of approximation (RMSEA) indicated a good fit with the hypothesized measurement model (NNFI $=0.95$, $\mathrm{CFI}=0.96$, IFI $=0.96$, and RMSEA $=0.05)(\mathrm{Hu} \&$ Bentler, 1999) (Table 1). The ratio of the chi-square to the degree of freedom was 1.38 , which is below 4 . Furthermore, all the factor loadings were statistically significant $(p<0.01)$. The composite reliabilities of RMO, PMO, new product performance, and firm performance were $0.81,0.88,0.96$, and 0.92 , respectively. They were both $>0.70$ and thus acceptable (see Nunnally, 1978). Only competition intensity had a composite reliability of 0.66 , which is close to 0.70 . Thus, we concluded that the measures demonstrated adequate convergent validity and reliability.

We examined discriminant validity by calculating the shared variance between all possible pairs of constructs, verifying that they were lower than the average variance extracted for the individual constructs (Fornell \& Larcker, 1981). These results showed that the average variance extracted by the measure of each factor was larger than the squared correlation of that factor's measure with the measures of all other factors in the model (see Table 1). Given these values, we concluded that all factors in the measurement model possessed strong discriminant validity. In light of this evaluation, all factors in the measurement model possessed both convergent and discriminant validity, and the CFA model adequately fit the data (see Table 1). Furthermore, we used Harman's one-factor test in CFA to examine common method variance (CMV). We compared the fit indices of the five-factor CFA model with that of the one-factor CFA model. A worse fit for the one-factor model suggested that CMV did not pose a serious threat (Podsakoff \& Organ, 1986). The one-factor model had a chi-square of 1255.42 with 230 degrees of freedom, and the five-factor measurement model had a chisquare of 302.81 with 220 degrees of freedom. Thus, the chi-square difference was significant $\left(\Delta \chi^{2}=952.61, \Delta \mathrm{df}=10, p<0.05\right)$, suggesting that CMV may not be a problem in the measurement model.

\subsection{Hypothesis testing}

We estimated the hypothesized model by using structural equation modeling, with the EQS 6.1 program. To test the hypotheses including quadratic effects of RMO and PMO, we followed the two-step version of Ping's (1995) single-indicant estimation method for latent continuous variables. In the two-step estimation technique, first we calculated the loadings and error variances for the single indicators of quadratic variables $\left(\mathrm{RMO}^{2}\right.$ and $\mathrm{PMO}^{2}$ ) by using measurement model parameter estimates. Then, the structural model was specified by fixing the values for the single indicant loadings for quadratic variables and error variances to the appropriate calculated values.

Table 3 provides the results of the hypothesis testing, along with parameter estimates, their corresponding t-values, and the fit statistics. As Table 3 shows, the chi-square test was statistically significant $\left(\chi_{(348)}^{2}=\right.$ 598.49, $p<0.05)$. The scores achieved for the fit measures showed that the hypothesized model had somewhat reasonable fit with the data $(\mathrm{NNFI}=0.88, \mathrm{CFI}=0.90, \mathrm{IFI}=0.90$, and $\mathrm{RMSEA}=0.08)$.

Competitor alliances $(\beta=0.21 ; p<0.05)$ had a significant association with a firm's RMO, confirming $\mathrm{H} 1$. The effect of supplier alliances $(\beta=0.17 ; p<0.10)$ on a firm's RMO was not significant, thus not supporting H2. Our examination of the effect of a firm's new product 
Table 2

Means, standard deviations, and intercorrelations for the study constructs.

\begin{tabular}{|c|c|c|c|c|c|c|c|c|c|c|}
\hline & Mean & $\begin{array}{l}\text { Standard } \\
\text { deviation }\end{array}$ & $\begin{array}{l}\text { Competitor } \\
\text { alliances }\end{array}$ & $\begin{array}{l}\text { Supplier } \\
\text { alliances }\end{array}$ & $\begin{array}{l}\text { Institution } \\
\text { alliances }\end{array}$ & RMO & PMO & $\begin{array}{l}\text { New product } \\
\text { performance }\end{array}$ & $\begin{array}{l}\text { Firm } \\
\text { performance }\end{array}$ & $\begin{array}{l}\text { Competition } \\
\text { intensity }\end{array}$ \\
\hline Competitor alliances & 3.47 & 1.94 & - & 0.14 & $0.29^{*}$ & 0.18 & $0.24^{*}$ & 0.17 & 0.15 & 0.04 \\
\hline Supplier alliances & 5.28 & 1.57 & & - & $0.34^{*}$ & $0.20^{*}$ & $0.34^{*}$ & 0.13 & $0.21^{*}$ & -0.09 \\
\hline Research institution alliances & 3.59 & 1.83 & & & - & 0.15 & $0.33^{*}$ & 0.17 & $0.29^{*}$ & -0.05 \\
\hline RMO & 5.45 & 0.89 & & & & - & $0.60^{*}$ & $0.48^{*}$ & $0.33^{*}$ & 0.06 \\
\hline PMO & 4.60 & 1.22 & & & & & - & $0.50^{*}$ & $0.35^{*}$ & -0.08 \\
\hline New product performance & 5.06 & 0.97 & & & & & & - & $0.53^{*}$ & 0.02 \\
\hline Firm performance & 5.13 & 1.31 & & & & & & & - & 0.06 \\
\hline Competition intensity & 4.82 & 0.99 & & & & & & & & - \\
\hline
\end{tabular}

* Correlations are significant at the $p<0.05$ level.

alliances on PMO revealed that research institution alliances $(\beta=0.35$; $p<0.001$ ) were significantly and positively associated with PMO, in support of $\mathrm{H} 3$.

H4 and H5 predicted curvilinear effects of RMO and PMO on new product performance. The coefficient for the squared term for RMO was not significant $(\beta=0.10 ; p>0.10)$. However, the main effect of RMO on new product performance was significant $(\beta=0.34$; $p<$ 0.001 ); thus, $\mathrm{H} 4$ was partially supported. In support of $\mathrm{H} 5$, the coefficient for the squared term for PMO was significant and negative $(\beta=-0.33 ; p<0.05)$. The main effect of PMO was positive and significant $(\beta=0.28 ; p<0.005)$. Thus, we can conclude that there is an inverted $\mathrm{U}$-shaped relationship between PMO and new product performance.

The hypothesized model proposes that new product performance has a mediating effect on the relationship between RMO and PMO and firm performance. The results indicated that new product performance has a significant and positive effect on firm performance $(\beta=0.53 ; p<$ 0.001 ). In addition, we found significant effects of RMO and PMO on new product performance, as suggested. We tested an alternative specification of the model that included direct effects of RMO and PMO on firm performance. We tested this specification through a chi-square difference test (Cannon \& Homburg, 2001). These one-degree-of-freedom tests compared the improvement in the model's fit when the re-specified model frees a path from RMO or PMO directly to firm performance. When we added a path from RMO to firm performance, the fit did not improve $\left(\chi_{\text {diff }(1)}^{2}=0.51, p>0.10\right)$. Similarly, adding a path from PMO to firm performance did not improve the fit $\left(\chi^{2}\right.$ diff (1) $=1.76, p>$ $0.10)$. The direct effects of RMO $(\beta=0.07 ; p>0.10)$ and PMO $(\beta=$ $0.13 ; p>0.10)$ on firm performance were not significant. Overall, these results provide support for H6, which suggests that new product performance mediates the effects of RMO and PMO on firm performance.

\section{Discussion}

\subsection{Theoretical implications}

B2B marketing literature has long advocated the importance of business relationships as a means for learning from partners to achieve mutual benefits, such as lowered transaction costs and enhanced learning between partners (Hakansson \& Snehota, 1995; Rindfleisch \& Moorman, 2003; Wittman, Hunt, \& Arnett, 2009). Although Rindfleisch and Moorman (2003) examine how both horizontal alliances with competitors and vertical alliances dominated by channel partners affect a firm's orientation to create value for expressed customer needs over time, they do not focus on the role of different types of new product alliances in finding solutions to customers' latent needs. Similarly, despite the importance of research institutions in creating innovative customer solutions for latent needs (Bercovitz \& Feldman, 2007), no evidence reveals how alliance relationships with these types of partners may affect a firm's understanding and creation of customer value. For example, it is important to acknowledge that some variations may occur in the creation of customer value between vertical alliance partners (i.e., suppliers and research institutions) with manufacturing firms. This study advances previous research in the B2B marketing area by examining the implications of engaging in different types of new product alliances to create value for expressed customer needs (RMO) and to address latent customer needs (PMO) and, subsequently, improve firm performance.

The findings of this study suggest that B2B relationships in horizontal new product alliances with competitors that have overlapping knowledge and know-how enable manufacturing firms to develop an RMO. The positive influence of such alliances is aligned with the views favoring the benefits of these relationships in facilitating exploitative learning in NPD (Faems, Van Looy, \& Debackere, 2005; Luo,

Table 3

Results of hypothesis testing.

\begin{tabular}{|c|c|c|c|c|c|c|}
\hline & RMO & PMO & New product performance & Firm performance & Hypotheses & Conclusion \\
\hline Competitor alliances & $0.21^{*}(2.19)$ & & & & $\mathrm{H} 1$ & Supported \\
\hline Supplier alliances & $0.17^{\text {n.s. }}(1.79)$ & & & & $\mathrm{H} 2$ & Not supported \\
\hline Research institution alliances & & $0.35^{* * *}(3.70)$ & & & H3 & Supported \\
\hline RMO & & & $0.34^{* * *}(3.85)$ & & $\mathrm{H} 4$ & Partially supported \\
\hline RMO-squared & & & $0.10^{\text {n.s. }}(0.66)$ & & & \\
\hline PMO & & & $0.28^{* *}(3.11)$ & & H5 & Supported \\
\hline PMO-squared & & & $-0.33^{*}(-2.14)$ & & & \\
\hline New product performance & & & & $0.53^{* * * *}(5.80)$ & H6 & Supported \\
\hline Competition intensity & $0.06^{\text {n.s. }}(0.61)$ & $-0.09^{\text {n.s. }}(-0.88)$ & $0.14^{\text {n.s. }}(1.31)$ & $0.02^{\text {n.s. }}(0.23)$ & & \\
\hline Age & $0.01^{\text {n.s. }}(0.15)$ & $-0.08^{\text {n.s. }}(-0.90)$ & $0.08^{\text {n.s. }}(0.94)$ & $-0.06^{\text {n.s. }}(-0.77)$ & & \\
\hline
\end{tabular}

Model fit statistics: $\chi^{2}=598.49$ ( $\left.\mathrm{df}=348, p<0.05\right)$; NNFI $=0.88$; CFI $=0.90$; IFI $=0.90$; RMSEA $=0.08$; 90\% confidence interval of RMSEA $=(0.06,0.08)$.

n.s.: not significant (2-tailed test). Notes: t-values are in parentheses.

*** $p<0.001$.

** $p<0.005$

${ }^{*} p<0.05$. 
Rindfleisch, \& Tse, 2007; Rindfleisch \& Moorman, 2003; Wu, 2014). Compared with Rindfleisch and Moorman's (2003) study, our finding suggests that horizontal alliances do not necessarily make firms become less customer oriented but rather become insensitive to future customer needs. In line with previous research in B2B marketing, this finding recognizes that negative effects of horizontal alliances, such as lower levels of mutual trust and interdependency and higher levels of partner opportunism, may affect the creation of value for customers (Pressey, 2004; Rindfleisch, 2000; Rindfleisch \& Moorman, 2003). Our study extends B2B marketing literature by revealing that horizontal alliances may not necessarily lead to opportunistic and value-destroying behavior or collusive conduct (e.g., price fixing, agreements to restrict production and innovation) (Pressey, 2004; Rindfleisch \& Moorman, 2003); rather, these relationships may provide a different type of value to customers by supporting the creation of new solutions for their expressed needs.

The study, on the other hand, does not provide any support for the effect of vertical new product alliances with suppliers on a manufacturing firm's RMO. This result contradicts with Rindfleisch and Moorman's (2003) study, which shows that alliances dominated by channel members enable a stable level of customer orientation for satisfying expressed customer needs. In this sense, our study builds on the notion which suggests that increased knowledge similarity between partners enhances the absorption and assimilation of knowledge in B2B alliance relationships (Atuahene-Gima et al., 2005; Cohen \& Levinthal, 1990; Lane et al., 2006). For example, manufacturers often have higher levels of relational ties with their suppliers due to their longer span relationships compared to other types of partners. Despite the knowledge similarity between suppliers and manufacturing firms, strong relational ties between these partners may prevent manufacturers' knowledge acquisition and efforts to learn additional insights and knowledge from their suppliers (Zhou, Zhang, Sheng, Xie, \& Bao, 2014). Similarly, suppliers may not easily redeploy their idiosyncratic relational investment for one manufacturer to another, which may affect the level of their knowledge transfer to different manufacturers (Dyer \& Hatch, 2006). Moreover, manufacturing firms may mainly rely on transactional relationships in their product development efforts with suppliers rather than collaborative relationships and co-creation of new offerings. This may, in turn, prevent absorption of tacit knowledge and learning additional insights about creating value for expressed customer needs.

This study further shows that new product alliances with research institutions support the development of solutions for latent customer needs through explorative learning (Faems et al., 2005; George et al., 2002; Skippari et al., 2017). This finding has implications for business relationships in terms of composition of a portfolio of both horizontal and vertical new product alliance partners. On the one hand, studies suggest that alliance portfolio diversity enhances either a firm's internal innovation efforts to create customer value (e.g., Faems et al., 2010) or innovativeness of solutions related to latent customer needs (e.g., Cui \& O'Connor, 2012). On the other hand, studies show that excessive alliance portfolio diversity may produce a diminishing returns effect on the innovativeness of customer solutions (Wuyts \& Dutta, 2014). In this sense, our study provides insights into these conflicting findings by showing that the type of alliance partner may not always bring similar benefits to the partner firms. Thus, rather than the diversity of partners within an alliance portfolio, it would be more appropriate for firms to consider how individual effects of each alliance partner type affect the creation of different types of value for customers. Previous studies have examined the issue from a firm's learning orientation perspective (e.g., Atuahene-Gima et al., 2005; Tsai et al., 2008). Our study extends this to the B2B marketing literature by examining how RMO and PMO developed through learning in new product alliances affect an industrial manufacturing firm's new product and overall performance.

The findings of this study show that RMO developed in a B2B alliance context leads to increased new product performance. In line with Tsai et al.'s (2008) study, but contrary to Atuahene-Gima et al.'s (2005) empirical findings, the analysis did not identify any curvilinear relationship between RMO and new product performance. This result may be specific to the contextual attributes of this study. Traditionally, manufacturing firms in Turkey have been superior in creating incrementally new products using novel combinations of existing knowledge domains. Therefore, the performance of their new products can be constantly improved by acquiring a good understanding of existing customer needs and requirements. In addition, Turkey has a higher uncertainty-avoidance index than other industrialized economies (Hofstede, 2001). Previous studies suggest that alliance partners operating in high-uncertainty-avoidance contexts would be more committed to providing market-oriented firms with new insights that do not undermine the sustainability of their market position (Grinstein, 2008). Thus, the increasing effect of RMO on new product performance in a culture characterized by high uncertainty avoidance does not seem to be a surprising result.

Moreover, as opposed to Atuahene-Gima et al.'s (2005) findings, this study finds that PMO developed in vertical new product alliances has a curvilinear effect (i.e., inverted $U$ shape) on new product performance. Such an effect can again be attributed to Turkey's high-uncertaintyavoidance culture. More specifically, new products that do not align with deeply rooted customer practices may face challenges in terms of market diffusion. As a result, beyond a certain point, heightened PMO, targeting latent customer needs and the requirement to learn new consumption practices, may result in negative performance returns in the market. This finding reflects organizational learning theory in the sense that excessive proactiveness and knowledge exploration is detrimental for firms (Levinthal \& March, 1993; March, 1991). In particular, the results of this study reinforce the normative assumption of the organizational learning theory, which suggests that firms focusing on developing too many new ideas are often faced with increased experimentation costs to find novel solutions for unarticulated market needs with little benefits in return (March, 1991).

This study contributes to previous research that has overlooked the mediating role of new product performance in the relationship between $\mathrm{PMO}$ and RMO of industrial firms and their firm performance in a single study (e.g., Han et al., 1998; Zhou et al., 2005). In this sense, this study extends these studies by showing that despite the differential effects of diverse types of MOs, new product performance consistently mediates the effects of RMO and PMO developed in a new product alliance context on firm performance. Therefore, ensuring new product success is paramount to convert the benefits of MO (i.e., RMO and PMO) developed in new product alliances to overall firm performance.

Finally, this study contributes to MO research by focusing on a developing country-Turkey. So far, research has explored the roles of new product alliances in the two MO types in the context of developed countries (e.g., Hernandez-Espallardo \& Arcas-Lario, 2003; Rindfleisch \& Moorman, 2003). However, manufacturing firms in emerging economies such as Turkey mainly produce low-value and undifferentiated offerings and supply contract manufacturing to firms from developed countries. Thus, they often lack an established intra-firm infrastructure and a sufficient level of knowledge and know-how to create value and unique solutions for expressed and latent customer needs through the two types of MO. They also have limited external sources of funding (e.g., government initiatives), which restricts their learning opportunities. Thus, in emerging economies, the different forms of B2B new product alliances constitute a highly significant determinant for the development of RMO and PMO.

\subsection{Managerial implications}

This study has several managerial implications. First, new product alliances with competitors enable firms to successfully develop and apply RMO to achieve superior new product performance outcomes. It is important for managers to recognize that such alliances enable firms to engage in exploitative learning and recombine existing 
knowledge to produce new solutions for existing customer needs in a cost-effective and timely manner.

Second, managers need to be aware of and act on the learning barriers in new product alliances with their suppliers. In particular, it is essential to ensure that manufacturing firms do not excessively rely on suppliers in their collaborative product development efforts. The odds for learning tacit knowledge and additional know-how on creating customer value from suppliers can be enhanced if manufacturers increase the level of their co-development endeavors.

Third, firms aiming to become PMO focused need to expand their network with research institutions, which hold high levels of knowledge non-redundancy and know-how. In this way, they can identify new opportunities for satisfying unexplored customer needs. In particular, engaging in vertical new product alliances with research institutions can help firms undertake exploratory research and learning and access dissimilar knowledge domains from a greater pool of knowledge resources. In turn, this information will enable them to learn how to most successfully address future customer needs, which is something that is more difficult to achieve through horizontal new product alliances with competitors and vertical new product alliances with suppliers.

Fourth, manufacturing firms need to realize that diverse types of MOs are important to achieve superior new product performance outcomes and eventually better firm performance. Therefore, firms need to invest in knowledge resources to develop an RMO and a PMO that will afford them sustainable performance benefits. Firms also need to ensure that their efforts in RMO and PMO are predominantly oriented toward the achievement of new product objectives.

Finally, market-oriented firms need to consider product and market fit in their NPD decisions, because incompatibility between solutions to latent customer needs and well-entrenched practices in certain markets may overshadow the benefits of these solutions and consequently act as barriers to their market diffusion. Overall, managers need to realize that forming the right types of alliances will enable their firms to develop different types of MO and thus achieve new product and firm performance objectives in today's technologically turbulent business environments, which demand swift responses to customer needs.

\subsection{Limitations and further research}

This study has several limitations, which constitute fruitful avenues for further research. First, this study mainly examined the effects of external NPD efforts (i.e., new product alliances) on the development of diverse MO types. It did not measure in-house NPD activities of the sample firms and thus excluded the effects of internal NPD efforts on RMO and PMO. Further research could examine how ambidextrous use of internal and external NPD efforts influences the development of RMO and PMO.

Second, this study did not consider the importance of a new product alliance for the participant firms. This is important because research has found that alliance importance is a vital determinant of a firm's behavior and performance (Deeds \& Rothaermel, 2003; Walter, Walter, \& Muller, 2015). That is, the importance of a new product alliance as an exogenous or moderator variable may have an influence on MO behaviors and eventual performance outcomes.

Third, this research excluded the role of certain moderators in the proposed relationships. In particular, it is significant to recognize how knowledge integration mechanisms influence the role of new product alliances in the development of a firm's MO. Understanding the extent to which external information attained from alliance partners is properly integrated into internal organizational units would offer a clearer picture of the effect of new product alliances on the formation of different types of MO. The moderating roles of control mechanisms, inter-firm trust, and embedded ties were also missing in this research. For example, Rindfleisch and Moorman (2003) find that the negative impact of alliances with competitors on a firm's customer orientation was attenuated by neutral third-party monitoring and a high degree of relational ties between partners. Including these factors as moderating effects might mean that alliances with competitors may sometimes motivate firms to engage in knowledge exploration to develop and successfully implement a PMO.

This research has limitations in measuring different types of new product alliances with a single-item statement. For example, Luo et al. (2007) assess the intensity of competitor alliance activities by using multiple-item questions such as R\&D, NPD, and technology improvement with competitor firms. Similarly, Lau, Tang, and Yam (2010) use multiple items on product information sharing and co-development with suppliers to measure the degree of NPD engagement with suppliers. Thus, employing multiple-item scales would generate a more comprehensive understanding of how a range of NPD activities undertaken with particularly competitors and research institutions can aid in the development of a manufacturing partner's MO. Finally, the structural model in this research had somewhat reasonable fit as the NNFI was 0.88 .

\section{References}

Anderson, J. C., \& Gerbing, D. W. (1988). Structural equation modeling in practice: A review and recommended two-step approach. Psychological Bulletin, 103, 411-423.

Antoncic, B., \& Prodan, I. (2008). Alliances, corporate technological entrepreneurship and firm performance: Testing a model on manufacturing firms. Technovation, 28 , 257-265.

Armstrong, J. S., \& Overton, T. S. (1977). Estimating nonresponse bias in mail surveys. Journal of Marketing Research, 14, 396-402.

Atuahene-Gima, K. (1995). An exploratory analysis of the impact of market orientation on new product performance. Journal of Product Innovation Management, 12, 275-293.

Atuahene-Gima, K. (1996). Market orientation and innovation. Journal of Business Research, 35, 93-103.

Atuahene-Gima, K., \& Ko, A. (2001). An empirical investigation of the effect of market orientation and entrepreneurship orientation alignment on product innovation. Organization Science, 12, 54-74

Atuahene-Gima, K., Slater, S. F., \& Olson, E. M. (2005). The contingent value of responsive and proactive market orientations for new product program performance. Journal of Product Innovation Management, 22, 464-482.

Bagozzi, R. P., Yi, Y., \& Phillips, L. W. (1991). Assessing construct validity in organizational research. Administrative Science Quarterly, 36, 421-458.

Baker, W. E., \& Sinkula, J. M. (1999). Learning orientation, market orientation, and innovation: Integrating and extending models of organizational performance. Journal of Market-Focused Management, 4, 295-308.

Baker, W. E., \& Sinkula, J. M. (2005). Market orientation and the new product paradox. Journal of Product Innovation Management, 22, 483-502.

Baker, W. E., \& Sinkula, J. M. (2007). Does market orientation facilitate balanced innovation programmes? An organizational learning perspective. Journal of Product Innovation Management, 24, 316-334.

Barney, J. B. (1991). Firm resources and sustained competitive advantage. Journal of Management, 17, 99-120.

Baum, J. A. C., Calabrese, T. \& Silverman, B. S. (2000). Don't go it alone: Alliance network composition and startups' performance in Canadian biotechnology. Strategic Management Journal, 21, 267-294.

Belderbos, R., Carree, M., Diederen, B., Lokshin, B., \& Veugelers, R. (2004). Heterogeneity in R\&D cooperation strategies. International Journal of Industrial Organization, 22, $1237-1263$

Bentler, P. M. (1995). EQS structural equations program manual. Encino, CA: Multivariate Software.

Bercovitz, J. E. L., \& Feldman, M. P. (2007). Fishing upstream: Firm innovation strategy and university research alliances. Research Policy, 36, 930-948.

Berghman, L., Matthyssens, P., \& Vandenbempt, K. (2006). Building competences for new customer value creation: An exploratory study. Industrial Marketing Management, 35, 961-973.

Blocker, C. P., Flint, D. J., Myers, M. B., \& Slater, S. F. (2011). Proactive customer orientation and its role for creating customer value in global markets. Journal of the Academy of Marketing Science, 39, 216-233.

Bonaccorsi, A., \& Lipparini, A. (1994). Strategic partnerships in new product development: An Italian case study. Journal of Product Innovation Management, 11, 134-145.

Boso, N., Story, V. M., \& Cadogan, J. W. (2013). Entrepreneurial orientation, market orientation, network ties, and performance: Study of entrepreneurial firms in a developing economy. Journal of Business Venturing, 28, 708-727.

Burt, R. S. (1992). Structural holes: The social structure of competition. Harvard University Press.

Cannon, J. P., \& Homburg, C. (2001). Buyer-supplier relationships and customer firm costs. Journal of Marketing, 65, 29-43.

Christensen, M. C., \& Bower, J. L. (1996). Customer power, strategic investment, and the failure of leading firms. Strategic Management Journal, 17, 197-218.

Cohen, W. M., \& Levinthal, D. A. (1990). Absorptive capacity: A new perspective on learning and innovation. Administrative Science Quarterly, 35, 128-152. 
Cousins, P. D., \& Lawson, B. (2007). The effect of socialization mechanisms and performance measurement on supplier integration in new product development. British Journal of Management, 18, 311-326.

Cui, A. S., \& O'Connor, G. (2012). Alliance portfolio resource diversity and firm innovation. Journal of Marketing, 76, 24-43.

Day, G. S. (2011). Closing the marketing capabilities gap. Journal of Marketing, 75 , 183-195.

Day, G. S., \& Nedungadi, P. (1994). Managerial representations of competitive advantage. Journal of Marketing, 58, 31-44.

De Toni, A., \& Nassimbeni, G. (2001). A method for the evaluation of suppliers' co-design effort. International Journal of Production Economics, 72, 169-180.

Deeds, D. L., \& Rothaermel, F. T. (2003). Honeymoons and liabilities: The relationship between age and performance in research and development alliances. Journal of Product Innovation Management, 20, 468-484.

Duysters, G., \& Lokshin, B. (2011). Determinants of alliance portfolio complexity and its effect on innovative performance of companies. Journal of Product Innovation Management, 28, 570-585.

Dyer, J. H., \& Singh, H. (1998). The relational view: Cooperative strategy and sources of interorganizational competitive advantage. The Academic Management Review, 23, 660-679.

Dyer, J. H., \& Hatch, N. W. (2006). Relation-specific capabilities and barriers to knowledge transfers: creating advantage through network relationships. Strategic Management Journal, 27, 701-719.

Elg, U. (2002). Inter-firm market orientation: Its significance and antecedents in distribution networks. Journal of Marketing Management, 18, 633-655.

Elg, U. (2007). Market orientation as interfirm cooperation: An international study of the grocery sector. European Management Journal, 25, 283-297.

Faems, D., de Visser, M., Andries, P., \& Van Looy, B. (2010). Technology alliance portfolios and financial performance: Value-enhancing and cost-increasing effects of open innovation. Journal of Product Innovation Management, 27, 785-796.

Faems, D., Van Looy, B., \& Debackere, K. (2005). Interorganizational collaboration and innovation: Toward a portfolio approach. Journal of Product Innovation Management, 22, 238-250.

Fornell, C., \& Larcker, D. F. (1981). Evaluating structural equation models with unobservable variables and measurement error. Journal of Marketing Research, 18, 39-50.

Galaskiewicz, J. (1985). Interorganizational relations. Annual Review of Sociology, 11, 281-304.

Garud, R. (1994). Cooperative and competitive behaviors during the process of creative destruction. Research Policy, 23, 385-394.

George, G., Zahra, S. A., \& Wood, D. R. (2002). The effects of business-university alliances on innovative output and financial performance: A study of publicly traded biotechnology companies. Journal of Business Venturing, 17, 577-609.

Gotteland, D., \& Boule, J. -M. (2006). The market orientation-new product performance relationship: Redefining the moderating role of environmental conditions. International Journal of Research in Marketing, 23, 171-185.

Grewal, R., \& Tansuhaj, P. (2001). Building organizational capabilities for managing economic crisis: The role of market orientation and strategic flexibility. Journal of Marketing, 65, 67-80.

Grinstein, A. (2008). The effect of market orientation and its components on innovation consequences: A meta-analysis. Journal of the Academy of Marketing Science, 36, $166-173$.

Hakansson, H., \& Snehota, I. (1995). Developing relationships in business networks. Boston: International Thomson Press.

Han, J. K., Kim, N., \& Srivastava, R. (1998). Market orientation and organizational performance: Is innovation a missing link? Journal of Marketing, 62, 30-45.

Henard, D. H., \& Szymanski, D. M. (2001). Why some new products are more successful than others. Journal of Marketing Research, 38, 362-375.

Hernandez-Espallardo, M., \& Arcas-Lario, N. (2003). The effects of authoritative mechanisms of coordination on market orientation in asymmetrical channel partnerships. International Journal of Research in Marketing, 20, 133-152.

Hess, A. M., \& Rothaermel, F. T. (2011). When are assets complementary? Star scientists, strategic alliances and innovation in the pharmaceutical industry. Strategic Management Journal, 32, 895-909.

Hoang, H., \& Rothaermel, F. T. (2010). Leveraging internal and external experience: Exploration, exploitation and R\&D project performance. Strategic Management Journal, 31, $734-758$.

Hofstede, G. (2001). Culture's consequences: Comparing values, behaviors, institutions, and organizations across nations. Thousand Oaks, CA: Sage.

Hu, L., \& Bentler, P. M. (1999). Cutoff criteria for fit indexes in covariance structure analysis: Conventional criteria versus new alternatives. Structural Equation Modeling: A Multidisciplinary Journal, 6, 1-55.

Hult, G. T., \& Kethchen, D. J., Jr. (2001). Does market orientation matter? A test of the relationship between positional advantage and performance. Strategic Management Journal, 22, 899-906.

Inemek, A., \& Matthyssens, P. (2013). The impact of buyer-supplier relationships on supplier innovativeness: An empirical study in cross-border supply networks. Industrial Marketing Management, 42, 580-594.

Jaeger, N. A., Zacharias, N. A., \& Brettel, M. (2016). Nonlinear and dynamic effects of responsive and proactive market orientation: A longitudinal investigation. International Journal of Research in Marketing, 33, 767-779.

Jaworski, B. J., \& Kohli, A. K. (1993). Market orientation: Antecedents and consequences. Journal of Marketing, 57, 53-70.

Jaworski, B. J., Kohli, A. K., \& Sahay, A. (2000). Market-driven versus driving markets. Journal of the Academy of Marketing Science, 28, 45-54.
Jiménez-Jiménez, D., \& Cegarra-Navarro, J. G. (2007). The performance effect of organizational learning and market orientation. Industrial Marketing Management, 36, 694-708.

Katila, R. (2000). In search of innovation: search determinants of new product introductions. Ph.D. Dissertation The University of Texas at Austin.

Kim, N., \& Atuahene-Gima, K. (2010). Using exploratory and exploitative market learning for new product development. Journal of Product Innovation Management, 27 519-539.

Kirca, A. H., Jayachandran, S., \& Bearden, W. O. (2005). Market orientation: A meta-analytic review and assessment of its antecedents and impact on performance. Journal of Marketing, 69, 24-41.

Kohli, A. K., \& Jaworski, B. J. (1990). Market orientation: The construct, research propositions and managerial implications. Journal of Marketing, 54, 1-18.

Kotabe, M., Mol, M. J., \& Murray, J. Y. (2008). Outsourcing, performance and the role of ecommerce: A dynamic perspective. Industrial Marketing Management, 37, 37-45.

Koufteros, X., Vonderembse, M., \& Jayaram, J. (2005). Internal and external integration for product development: The contingency effects of uncertainty, equivocality, and platform strategy. Decision Sciences, 36, 97-133.

Koza, M. P., \& Lewin, A. Y. (1998). The co-evolution of strategic alliances. Organization Science, 9, 255-264.

Kumar, N., Scheer, L., \& Kotler, P. (2000). From market-driven to market-driving. European Management Journal, 18, 129-141.

Lambe, C. J., Morgan, R., Sheng, S., \& Kutwaroo, G. (2009). Alliance-based new product development success: The role of formalization in exploration and exploitation contexts. Journal of Business-to-Business Marketing, 16, 242-275.

Lambert, R. (2003). Lambert review of business-university collaboration. HMSO.

Lane, P. J., \& Lubatkin, M. (1998). Relative absorptive capacity and interorganizational learning. Strategic Management Journal, 19, 461-477.

Lane, P. J., Koka, B. R., \& Pathak, S. (2006). The reification of absorptive capacity: A critical review and rejuvenation of the construct. Academy of Management Review, 31, 833-863.

Langerak, F., Hultink, E. J., \& Robben, H. S. J. (2004). The impact of market orientation, product advantage, and launch proficiency on new product performance and organizational performance. Journal of Product Innovation Management, 21, 79-94.

Lau, A. K. W., Tang, E., \& Yam, R. C. M. (2010). Effects of supplier and customer integration on product innovation and performance: Empirical evidence in Hong Kong manufacturers. Journal of Product Innovation Management, 27, 761-777.

Levinthal, D. A., \& March, J. G. (1993). The myopia of learning. Strategic Managemen Journal, 14, 95-112.

Levitas, E., \& McFadyen, M. A. (2009). Managing liquidity in research-intensive firms: Signaling and cash flow effects of patents and alliance activities. Strategic Management Journal, 30, 659-678

Lhuillery, S., \& Pfister, E. (2009). R\&D cooperation and failures in innovation projects: Empirical evidence from French CIS data. Research Policy, 38, 45-57.

Li, C. R., Lin, C. J., \& Chu, C. P. (2008). The nature of market orientation and the ambidexterity of innovations. Management Decision, 46, 1002-1026.

Lin, C., Wu, Y. -J., Chang, C., Wang, W., \& Lee, C. -Y. (2012). The alliance innovation performance of R\&D alliances - the absorptive capacity perspective. Technovation, 32 $282-292$.

Love, P. E. D., \& Gunasekaran, A. (1999). Learning alliances: A customer-supplier focus for continuous improvement in manufacturing. Industrial and Commercial Training, 31, 88-96.

Lukas, B. A., \& Ferrell, O. C. (2000). The effect of market orientation on product innovation. Journal of the Academy of Marketing Science, 28, 239-247.

Luo, X., Rindfleisch, A., \& Tse, D. K. (2007). Working with rivals: The impact of competitor alliances on financial performance. Journal of Marketing Research, 44, 73-83.

Makri, M., Hitt, M. A., \& Lane, P. J. (2010). Complementary technologies, knowledge relatedness, and invention outcomes in high technology mergers and acquisitions. Strategic Management Journal, 31, 602-628.

Mansfield, E. (1991). Academic research and industrial innovation. Research Policy, 20 $1-12$.

March, J. G. (1991). Exploration and exploitation in organizational learning. Organization Science, 2, 71-87.

Matsuno, K., \& Mentzer, J. T. (2000). The effects of strategy type on the market orientation-performance relationship. Journal of Marketing, 64, 1-16.

Menguc, B., Seigyoung, A., \& Yannopoulos, P. (2014). Customer and supplier involvement in design: The moderating role of incremental and radical innovation capability. Journal of Product Innovation Management, 31, 313-328.

Mention, A. L. (2011). Co-operation and co-opetition as open innovation practices in the service sector: Which influence on innovation novelty? Technovation, 31, 44-53.

Monjon, S., \& Waelbroeck, P. (2003). Assessing spillovers from universities to firms: Evidence from French firm-level data. International Journal of Industrial Organization, 21, $1255-1270$

Moorman, C. (1995). Organizational market information processes: Cultural antecedents and new product outcomes. Journal of Marketing Research, 32, 318-335.

Morgan, R. E., \& Berthon, P. (2008). Market orientation, generative learning, innovation strategy and business performance: Inter-relationships in bioscience firms. Journal of Management Studies, 45, 1330-1353.

Narver, J. C., \& Slater, S. F. (1990). The effect of a market orientation on business profitability. Journal of Marketing, 54, 20-35.

Narver, J. C., Slater, S. F., \& MacLachlan, D. L. (2004). Responsive and proactive market orientation and new product success. Journal of Product Innovation Management, 21, 334-347.

Nelson, R. R., \& Winter, S. G. (1982). An evolutionary theory of economic change. Harvard University Press. 
Nieto, M. J., \& Santamaria, L. (2007). The importance of diverse collaboration networks for the novelty of product innovation. Technovation, 27, 367-377.

Nunnally, J. C. (1978). Psychometric theory (2nd ed.). New York: McGraw-Hill.

OECD (2013). OECD science, technology and industry scoreboard 2013. OECD Publishing. http://dx.doi.org/10.1787/sti_scoreboard-2013-en.

Paladino, A. (2007). Investigating the drivers of innovation and new product success: A comparison of strategic orientations. Journal of Product Innovation Management, 24, 534-553.

Pelham, A. M., \& Wilson, D. T. (1996). A longitudinal study of the impact of market structure, firm structure, strategy, and market orientation culture on dimensions of smallfirm performance. Journal of the Academy of Marketing Science, 24, 7-43.

Pfeffer, J., \& Nowak, P. (1976). Joint-ventures and interorganizational interdependence. Administrative Science Quarterly, 21, 398-418.

Ping, R. A., Jr. (1995). A parsimonious estimating technique for interaction and quadratic latent variables. Journal of Marketing Research, 32, 336-347.

Podsakoff, P. M., \& Organ, D. W. (1986). Self-reports in organizational research: Problems and prospects. Journal of Management, 12, 531-544.

Pressey, R. L. (2004). Conservation planning and biodiversity: Assembling the best data for the job. Conservation Biology, 18, 1677-1681.

Rindfleisch, A. (2000). Organizational trust and interfirm cooperation: An examination of horizontal versus vertical alliances. Marketing Letters, 11, 81-95.

Rindfleisch, A., \& Moorman, C. (2001). The acquisition and utilization of information in new product alliances: A strength of ties perspective. Journal of Marketing, 65, 1-18.

Rindfleisch, A., \& Moorman, C. (2003). Interfirm cooperation and customer orientation. Journal of Marketing Research, 40, 421-436.

Saini, A., \& Johnson, J. L. (2005). Organizational capabilities in e-commerce: An empirical investigation of e-brokerage service providers. Journal of the Academy of Marketing Science, 33, 360-375.

Siguaw, J. A., Simpson, P. M., \& Baker, T. L. (1998). Effects of supplier market orientation in distributor market orientation and the channel relationship: The distributor perspective. Journal of Marketing, 62, 99-111.

Skippari, M., Laukkanen, M., \& Salo, J. (2017). Cognitive barriers to collaborative innovation generation in supply chain relationships. Industrial Marketing Management, 62, 108-117.

Slater, S. F., \& Mohr, J. J. (2006). Successful development and commercialization of technological innovation: Insights based on strategy type. Journal of Product Innovation Management, 23, 26-33.

Slater, S. F., \& Narver, J. C. (1994). Does competitive environment moderate the market orientation-performance relationship? Journal of Marketing, 58, 46-55.

Slater, S. F., \& Narver, J. C. (1995). Market orientation and the learning organization. Journal of Marketing, 59, 63-74

Slater, S. F., \& Narver, J. C. (1998). Customer-led and market-oriented: Let's not confuse the two. Strategic Management Journal, 19, 1001-1006.

Song, M., \& Thieme, J. (2009). The role of suppliers in market intelligence gathering for radical and incremental innovation. Journal of Product Innovation Management, 26 , 43-57.

Thomas, E. (2013). Supplier integration in new product development: Computer mediated communication, knowledge exchange and buyer performance. Industrial Marketing Management, 42, 890-899.

Tsai, K. H., Chou, C., \& Kuo, J. H. (2008). The curvilinear relationships between responsive and proactive market orientations and new product performance: A contingent link. Industrial Marketing Management, 37, 884-894.

Un, C. A., Cuervo-Cazurra, A., \& Asakawa, K. (2010). R\&D collaborations and product innovation. Journal of Product Innovation Management, 27, 673-689.

Vanhaverbeke, W., Gilsing, V., Beerkens, B., \& Duysters, G. (2009). The role of alliance network redundancy in the creation of core and non-core technologies. Journal of Management Studies, 46, 215-244.

Von Hippel, E. (1986). Lead users: A source of novel product concepts. Management Science, 32, 791-805

Voola, R., \& O'Cass, A. (2010). Implementing competitive strategies: The role of responsive and proactive market orientations. European Journal of Marketing, 44, 245-266.
Waarts, E., \& Van Everdingen, Y. (2005). The influence of national culture on the adoption status of innovations: An empirical study of firms across Europe. European Management Journal, 23, 601-610.

Walter, S., Walter, A., \& Muller, D. (2015). Formalization, communication quality, and opportunistic behavior in R\&D alliances between competitors. Journal of Product Innovation Management, 32, 954-970.

Wei, Y., \& Morgan, N. A. (2004). Supportiveness of organizational climate, market orientation, and new product performance in Chinese firms. Journal of Product Innovation Management, 21, 375-388.

Wittman, M. C., Hunt, S. D., \& Arnett, D. B. (2009). Explaining alliance success: Competences, resources, relational factors, and resource-advantage theory. Industrial Marketing Management, 38, 734-756.

$\mathrm{Wu}, \mathrm{J}$. (2014). Cooperation with competitors and product innovation: Moderating effects of technological capability and alliances with universities. Industrial Marketing Management, 43, 199-209.

Wuyts, S. H., \& Dutta, S. (2014). Benefiting from alliance portfolio diversity: The role of past internal knowledge creation strategy. Journal of Management, 40, 1653-1674.

Xu, S., Wu, F., \& Cavusgil, E. (2013). Complements or substitutes? Internal technological strength, competitor alliance participation, and innovation development. Journal of Product Innovation Management, 30, 750-762.

Yannopoulos, P., Auh, S., \& Menguc, B. (2012). Achieving fit between learning and market orientation: Implications for new product performance. Journal of Product Innovation Management, 29, 531-545.

Zeng, S. X., Xie, X. M., \& Tam, C. M. (2010). Relationship between cooperation networks and innovation performance of SMEs. Technovation, 30, 181-194.

Zhang, J., \& Duan, Y. (2010). The impact of different types of market orientation on product innovation performance: Evidence from Chinese manufacturers. Management Decision, 48, 849-867.

Zhang, H. Wu, F. \& Cui, S. C. (2015). Balancing market exploration and market exploitation in product innovation: A contingency perspective. International Journal of Research in Marketing, 32, 297-308

Zhou, K. Z., Yim, C. K., \& Tse, D. K. (2005). The effects of strategic orientations in technology- and market-based breakthrough innovation. Journal of Marketing, 69, 42-46.

Zhou, K. Z., Zhang, Q., Sheng, S., Xie, E., \& Bao, Y. (2014). Are relational ties always good for knowledge acquisition? Buyer - Supplier exchanges in China. Journal of Operations Management, 32, 88-98.

Sena Ozdemir (PhD, University of Portsmouth, UK) is a Lecturer in Marketing at Essex Business School, University of Essex. Her current research focuses on the areas of new product development, market orientation, and intra- and inter-firm cooperation behaviour and performance in emerging economies. She acts as the postgraduate programme director and teaches a range of marketing subjects. She has published in journals such as Industrial Marketing Management, Journal of Business Research and so forth.

Destan Kandemir ( $\mathrm{PhD}$, Michigan State University, USA) is an assistant professor of marketing in the Department of Management at Bilkent University. Her research interests include strategic marketing, innovation, and strategic alliances. Her publications have appeared in several marketing and management journals, such as Journal of Management, Journal of Product Innovation Management, Journal of the Academy of Marketing Science, Journal of International Marketing, and Industrial Marketing Management.

Teck-Yong Eng (PhD, University of Manchester, UK) is Professor of Marketing at the University of Southampton, Southampton Business School UK. His current research focuses on supply chain of grocery retailers, new product development, digital innovation and business networks particularly in emerging economies. His teaching interests include business marketing, new product development, supply chain management, and creativity and innovation. He has published articles in numerous blind peer reviewed academic journals including Journal of World Business, Asia Pacific Business Review, Industrial Marketing Management, Journal of Marketing Management, Entrepreneurship Theory and Practice, and Technovation. 